\title{
Estudo das possibilidades de iluminação cênica no Theatro José de Alencar
}

\section{Study of the possibilities of scenic lighting at the José de Alencar Theater}

Walter Façanha Freitas ${ }^{1}$

Francimara Nogueira Teixeira ${ }^{2}$

Gilson Brandão Costa ${ }^{3}$ 


\section{Resumo}

Esse artigo é um estudo das possibilidades relacionadas à iluminação cênica em um teatro monumento, o Theatro José de Alencar. O estudo foi desenvolvido partir de três etapas de coleta de dados: visita em campo, pesquisa documental e entrevistas. Para tal, foi criado e utilizado um guia, fundamentado em teóricos, como Simões (2015), Barroso (2002) e Camargo (2000), a fim de discutir e relacionar possibilidades cênicas na execução de projetos luminotécnicos. A pesquisa documental buscou informações históricas sobre as estruturas cenotécnicas do referido teatro. Das entrevistas se colheu dados empíricos envolvendo a iluminação cênica para, através de análise comparativa com as estruturas luminotécnicas avaliadas, encontrar um repertório de possibilidades técnico-artísticas para o referido teatro, a partir das visitas realizadas. Através do levantamento e da análise das possibilidades de iluminação cênica desse equipamento, esse estudo acredita poder contribuir assim para fortalecer o Theatro José de Alencar, ao produzir uma pesquisa que pode auxiliar os profissionais que se utilizam dele com subsídios técnicos mais precisos para a realização de seus projetos e criações.

Palavras-chaves: Iluminação cênica; teatro; possibilidades luminotécnicas

\section{Abstract}

This article is a study of the possibilities related to scenic lighting in a monument theater, the José de Alencar Theater. The study was developed from three stages of data collection: field visit, documentary research and interviews. To this end, a guide was created and used, based on theorists such as Simões (2015), Barroso (2002) and Camargo (2000), in order to discuss and relate scenic possibilities in project execution. lighting technicians. The documentary research sought historical information about the cenotechnical structures of the referred theater. From the interviews, empirical data were collected involving scenic lighting to, through a comparative analysis with the evaluated lighting structures, find a repertoire of technical and artistic possibilities for the theater, based on the visits made. Through the survey and analysis of the scenic lighting possibilities of this equipment, this study believes it can contribute to strengthen the José de Alencar Theater, by producing a research that can help professionals who use it more accurate technical subsidies to perform their work. projects and creations.

Keywords: Scenic lighting; theater; luminotechnical possibilities

\footnotetext{
${ }^{1}$ Mestre em Artes (PPGArtes/IFCE). Engenheiro Eletricista, formado pela Universidade Federal do Ceará (UFC) - whacanha@gmail.com

2 Profa. Dra. da Licenciatura em Teatro (IFCE) e dos Programas de Pós-Graduação em Artes da Universidade Federal do Ceará (PPGArtes/UFC) e do Instituto Federal de Educação, Ciência e Tecnologia do Ceará (PPGArtes/IFCE) - franteixeira00@gmail.com

${ }^{3}$ Prof. Dr. da Licenciatura em Teatro da Universidade Federal do Ceará (UFC) e do Programa de Pós-Graduação em Artes do Instituto Federal de Educação, Ciência e Tecnologia do Ceará (PPGArtes/IFCE) - gilbrandao@ufc.br 
Esse estudo 4 reúne as principais discussões que surgiram da pesquisa de campo realizada entre os anos de 2018 e 2019 no Theatro José de Alencar, equipamento cultural da Secretaria de Cultura do Estado do Ceará, inaugurado em 1910. Nesse artigo são apresentados os resultados das visitas técnicas ao Theatro, bem como a análise das entrevistas realizadas com diretores, iluminadores, técnicos, arquitetos e pesquisadores que participaram ou foram testemunhas das intervenções cenotécnicas e luminotécnicas que esse espaço teatral sofreu.

O objetivo principal é identificar possibilidades e limitações técnicas do Theatro José de Alencar para execução de projetos artísticos de iluminação cênica. Como objetivos específicos, essa pesquisa se propôs a: (i) analisar o processo de construção das estruturas luminotécnicas que o Theatro José de Alencar dispõe; (ii) identificar as limitações relacionadas às estruturas luminotécnicas do Theatro José de Alencar para receber projetos artísticos de iluminação cênica; e (iii) revelar as possibilidades de intervenções artísticas de iluminação cênica a partir das estruturas luminotécnicas encontradas, realizando também, de forma sintética, um levantamento sobre modelos de palco, vocabulário técnico e instrumentos de iluminação.

O estudo foi desenvolvido em três etapas de coleta de dados, de forma a atender aos objetivos específicos deste trabalho. Uma foi a visita em campo, a outra, pesquisa documental, e por fim, a realização de entrevistas. Visando avaliar as estruturas do referido espaço teatral, foi utilizado um guia, elaborado pelo pesquisador, fundamentado especialmente nas teorias de Simões (2015) e Camargo (2000), de forma a encontrar as dificuldades cênicas para a execução de projetos luminotécnicos, por meio da análise dos dados encontrados na visita em campo. Já a pesquisa documental teve a finalidade de encontrar informações históricas acerca do referido teatro, no que diz respeito à sua construção e idealização. A mesma foi realizada por meio de estudo de documentos e de literatura técnica em bibliotecas do Estado e do próprio espaço teatral. Para consolidar as informações coletadas, foram realizadas entrevistas com sujeitos envolvidos na gestão do espaço teatral, artistas e pesquisadores da história do teatro em questão. Através da análise das entrevistas, procuramos entender o referido espaço teatral, a partir da visão de pessoas que utilizam o mesmo, de forma frequente, para apresentação de seus espetáculos, e de outras que participaram da história do Theatro, sendo testemunhas das mudanças arquitetônicas, artísticas e políticas que o mesmo vivenciou, ao longo do tempo, dirigindo-o, ou escrevendo sobre ele, ou trabalhando diretamente nos restauros e modificações, que fizeram o Theatro José de Alencar atravessar mais de um século de existência e chegando à presente data ainda sendo um espaço importante a ser estudado, a ser descoberto e também por ser um local no qual se defende que poderia acompanhar a evolução da iluminação cênica .

Para um entendimento mais profundo do Theatro José de Alencar, nove visitas técnicas foram realizadas, gerando uma coleta de dados direcionadas aos objetivos desta pesquisa, assim como também foram conduzidas entrevistas, com a finalidade de obtenção de mais informações, acerca do objeto de estudo, que foram com-

\footnotetext{
${ }^{4}$ Esse estudo é fruto da pesquisa de mestrado de Walter Façanha Freitas, desenvolvida no programa de Pós-Graduação em Artes, do Instituto Federal de Educação, Ciência e Tecnologia do Estado do Ceará - IFCE e defendida em agosto de 2019.

Walter Façanha Freitas

Francimara Nogueira Teixeira

Gilson Brandão Costa

Urdimento, Florianópolis, v.1, n.37, p. 290-311, mar/abr 2020
} 
paradas com dados coletados em documentação escrita e observações técnicas, e ajudaram a encontrar um Theatro José de Alencar autêntico, genuíno e preparado para apresentar suas possibilidades luminotécnicas. Essas entrevistas foram realizadas com diversas pessoas ligadas ao Theatro José de Alencar, de alguma maneira. $\bigcirc$ critério para a escolha das mesmas, foi sua relevância e importância com relação ao objeto de estudo e sua atividade no Theatro. Foram entrevistadas as seguintes pessoas: Selma Santiago (atual diretora do Theatro José de Alencar), Haroldo Serra (diretor teatral e ator, diretor do Theatro entre 1972 e 1978), Oswald Barroso (diretor teatral, dramaturgo, diretor do Theatro entre 1991 e 1992), Ricardo Guilherme (ator, dramaturgo e diretor teatral), Jociel Teixeira (iluminador atuante no Theatro), Jorge Luiz (técnico do Theatro), Francisco Veloso (Funcionário do IPHAN ${ }^{5}$, atuante nas reformas do Theatro), Robledo Valente Duarte (Funcionário do IPHAN), Ismaél Solé (responsável pela reforma do Theatro José de Alencar em 1991).

Decidimos trazer os trechos mais importantes das entrevistas realizadas sobre o Theatro José de Alencar ao longo desse artigo, intercalando informações documentais com os depoimentos recolhidos.

\section{O Theatro e o Estado}

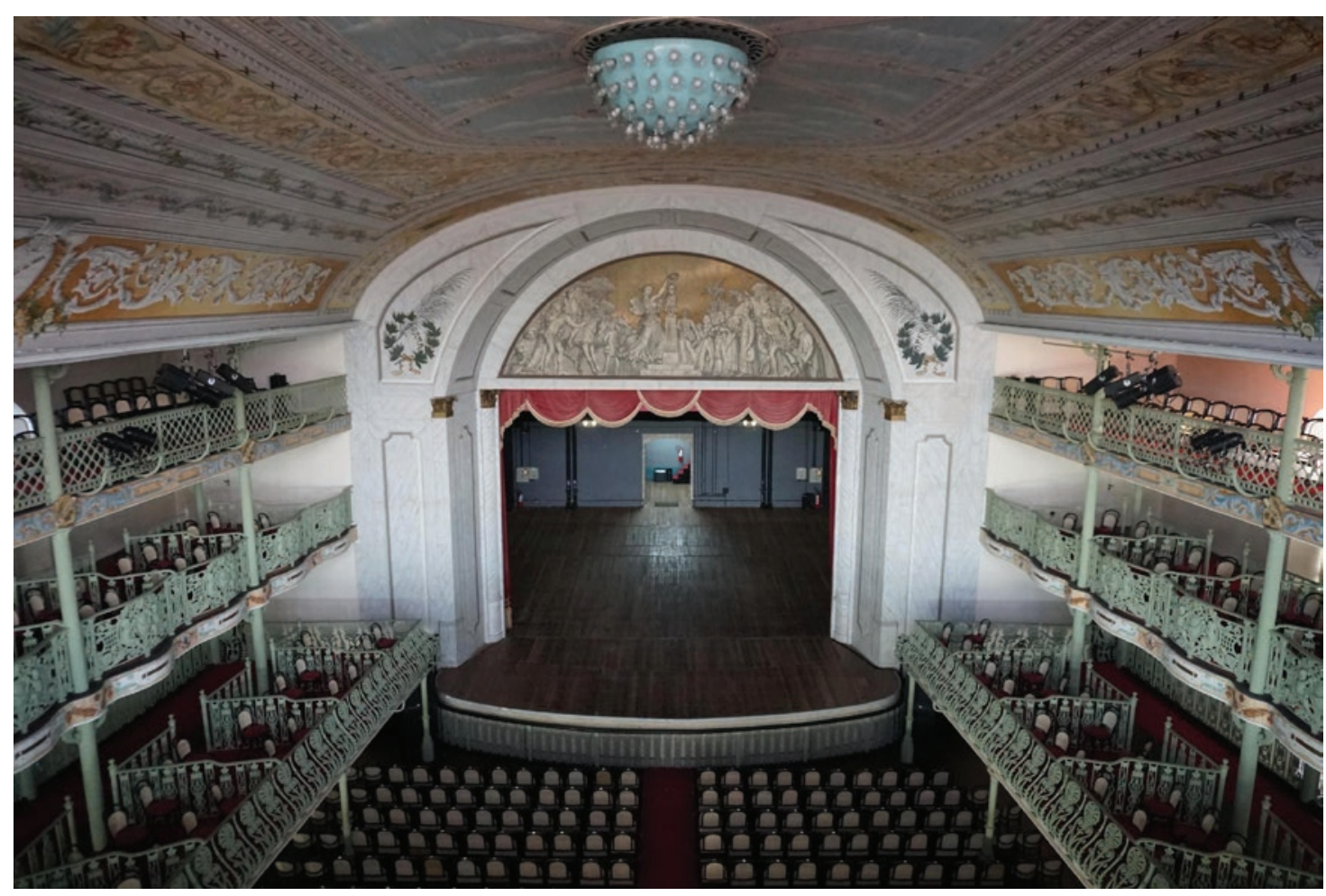

Figura 1 - Plateia do Theatro José de Alencar Fonte: Arquivo pessoal de Walter Façanha (2019). 
O Theatro José de Alencar (TJA) é considerado como o equipamento mais importante do Estado do Ceará. Inclusive é Patrimônio Artístico Nacional, tombado em 1964 (Figura 1). Foi totalmente restaurado entre os anos de 1989 e 1991, mantendo suas estruturas originais e amplamente modernizado, quanto às suas instalações técnicas. Atualmente é palco de grandes espetáculos e um centro de realizações das artes, contando com a participação efetiva de artistas, pensadores, produtores e do público em geral. O teatro, como destaca Oswald Barroso em seu livro Theatro José de Alencar: o teatro e a cidade (2002), se afirma como espaço aglutinador de pesquisa, formação, produção e difusão artística.

O Theatro José de Alencar foi edificado entre os anos de 1908 a 1910, para servir como teatro oficial ao público de Fortaleza. Essa construção tinha como objetivo impulsionar a vida artística da capital cearense e, também, estruturar um espaço teatral para receber companhias nacionais e internacionais, que tinham um nível de exigência artístico e técnico que não era atendido pelos outros teatros da cidade de Fortaleza (Lima, 2010). No depoimento de Francisco Veloso, do IPHAN, o mesmo nos diz que: "O Theatro começou a ser construído no centro da Praça José de Alencar. Hoje ainda encontramos fundações desse Theatro. Em uma mudança de administração, decidiu-se a mudança da localização, para o endereço atual." ${ }^{\prime}$

O Theatro foi edificado à italiana, seguindo os preceitos que regem esse estilo. O espaço teatral à italiana foi originalmente criado como um lugar fechado, elitista e quase secreto na cidade. A sua plateia deixa claro a segregação na sociedade, onde os lugares mais privilegiados, com melhor visibilidade da cena, melhor conforto de poltronas, e construído com materiais diferenciados e estruturados com mais esmero, ficam destinados às pessoas com maior poder aquisitivo e social. Dentro dessa edificação, duas áreas principais se apresentam. Uma, a do palco, onde a cena acontece, dissimulando a realidade e consolidando a ilusão. A outra, a da plateia, onde a sociedade se mostra, onde os espectadores se transformam em personagens, de um espetáculo que evidencia uma hierarquia social. Com a modernização dos espaços e da sociedade, essas áreas não mais segregam as pessoas, com o rigor originalmente concebido, mas a diferenciação dos valores dos ingressos para as diferentes áreas, ainda faz saltar aos olhos a nossa sociedade dividida (Barroso, 2002).

À época da concepção do Theatro, a arquitetura de ferro era muito apreciada pelos cearenses, não só por sua praticidade, mas por significar o que existia de mais tecnológico e avançado em termos de construção civil, além de lembrar os grandes centros cosmopolitas europeus, onde a elite cearense, composta por comerciantes importadores e exportadores, tentava manter uma proximidade, e os tinham como exemplo de civilização e riqueza. Essa estrutura foi encomendada à firma Walter MacFarlane \& Co., com sede em Glasgow, na Escócia, por Boris Frères, comerciante francês do ramo de importação e exportação, que possuía uma filial cearense e outra em Paris, em quem o governador do Estado, Nogueira Accioly, se apoiou (Barroso, 2002).

O Theatro José de Alencar passou por muitas reformas. A primeira foi em 1918, com a intenção de resolver o principal problema da época: trocar a iluminação cê-

6 Trecho da entrevista concedida a Walter Façanha Freitas, por Francisco Augusto Sales Veloso no dia 23 de abril de 2019.

Walter Façanha Freitas

Francimara Nogueira Teixeira

Gilson Brandão Costa

Urdimento, Florianópolis, v.1, n.37, p. 290-311, mar/abr 2020 
nica, composta por combustores a gás, pela iluminação elétrica. Essa mudança não objetivava primordialmente, alcançar recursos cenotécnicos mais primorosos à cena, nem alcançar mais segurança às estruturas, mas sim, transformar a plateia do Theatro em um local menos quente. Na época, as chamas provenientes da iluminação cênica, se uniam à imposição aos espectadores do uso de trajes longos e à falta de um condicionamento de ar, fazendo com que a plateia fosse comparada à um forno crematório. Como visto no capítulo 2, o Savoy Theatre, em Londres, já utilizava a iluminação elétrica desde 1881, ou seja, uma diferença de 37 anos comparando com a data de utilização da mesma tecnologia, no palco do José de Alencar.

A segunda reforma aconteceu no ano de 1937. O José de Alencar teve que fechar suas portas por determinação da Saúde Pública, depois que uma doença contagiosa se espalhou entre seus funcionários. É importante ressaltar que o Theatro estava edificado na vizinhança do Centro Estadual de Saúde, como nos informou Oswald Barroso:

O Theatro José de Alencar não possui mais nenhum figurino utilizado na sua inauguração. Também não tem equipamentos originais, utilizados em sua iluminação cênica, porque eles precisaram ser incinerados, depois da epidemia que atingiu a maioria dos funcionários do Theatro. ${ }^{7}$

A terceira reforma, aconteceu no ano de 1956, no governo de Paulo Sarasate. A caixa cênica foi refeita, mas sem alteração nos recursos luminotécnicos, apenas com troca de piso, coberta e sanitários. Mas o foco principal, como desde a concepção do Theatro, foi nas áreas de plateia. Já em 1954, mais precisamente no dia 10 de agosto, o Theatro José de Alencar foi tombado pelo Instituto do Patrimônio Histórico e Artístico Nacional (Barroso, 2002).

Outra pequena intervenção aconteceu em 1967, mas sem modificações consideráveis. Nesse tempo, o Theatro estava sofrendo fortemente com corrosões e oxidações em suas estruturas metálicas, e tinha boa parte de seu madeiramento corroído por cupins. Antes do José de Alencar entrar em colapso, aconteceu em 1973, a quarta grande reforma, sob o governo de César Cals. Essa foi considerada por alguns dos entrevistados, como a maior reforma já acontecida nele, como Haroldo Serra comentou: "Todos pensam que a reforma de 1991 foi a maior de todas. Mas a mais importante, foi a de 1973."8

Nessa reforma, finalmente o projeto do teatro-jardim pôde ser concretizado, já que houve a demolição do Centro Estadual de Saúde e deu lugar a um belo jardim, projetado por Burle Marx. Ela continuou priorizando a área de plateia, e tinha o objetivo principal de devolver a edificação, suas características originais. E praticamente todo o Theatro foi refeito, inclusive a recuperação de peças delicadas, que demandavam qualificação. A mão de obra utilizada foi dos funcionários da RFFSA ${ }^{9}$, ou seja, o governo do Estado se apoiou nos recursos de casa, para realizar toda essa reforma (Barroso, 2002).

\footnotetext{
7 Trecho da entrevista concedida a Walter Façanha Freitas por Raimundo Oswald Cavalcante Barroso no dia 10 de abril de 2019.

8 Trecho da entrevista concedida a Walter Façanha Freitas por Luiz Haroldo Cavalcante Serra no dia 11 de abril de 2019.

${ }^{9}$ RFFSA - Rede Ferroviária Federal

Walter Façanha Freitas

Francimara Nogueira Teixeira

Gilson Brandão Costa 
Na reforma de 1973, um item polêmico é utilizado, pela primeira vez, como forma de aumentar as possibilidades luminotécnicas do Theatro e resolver um problema, relatado também por Haroldo Serra, à época diretor do Theatro:

Nós não tínhamos muitos recursos técnicos. Os refletores da época não eram tão bons quanto os que eles têm hoje, que você pode colocar lá no final da plateia e ele chega até o palco. E precisávamos iluminar os espetáculos de frente. A solução foi colocar uma vara frontal no Theatro. Todo mundo reclamou. Mas com ela, conseguimos resolver o problema da falta de luz frontal. ${ }^{10}$

A utilização de uma vara frontal (Figura 2), para resolver esse problema de iluminação da época, e incrementar uma possibilidade luminotécnica, não levou em consideração a arquitetura original e as pinturas artísticas, no teto da plateia. Ou seja, a instalação dessa estrutura proporcionou um grande impacto visual à área de plateia. Os espectadores não conseguiam mais contemplar as obras de arte pintadas no teto, antes do espetáculo iniciar, devido à presença física da referida vara.

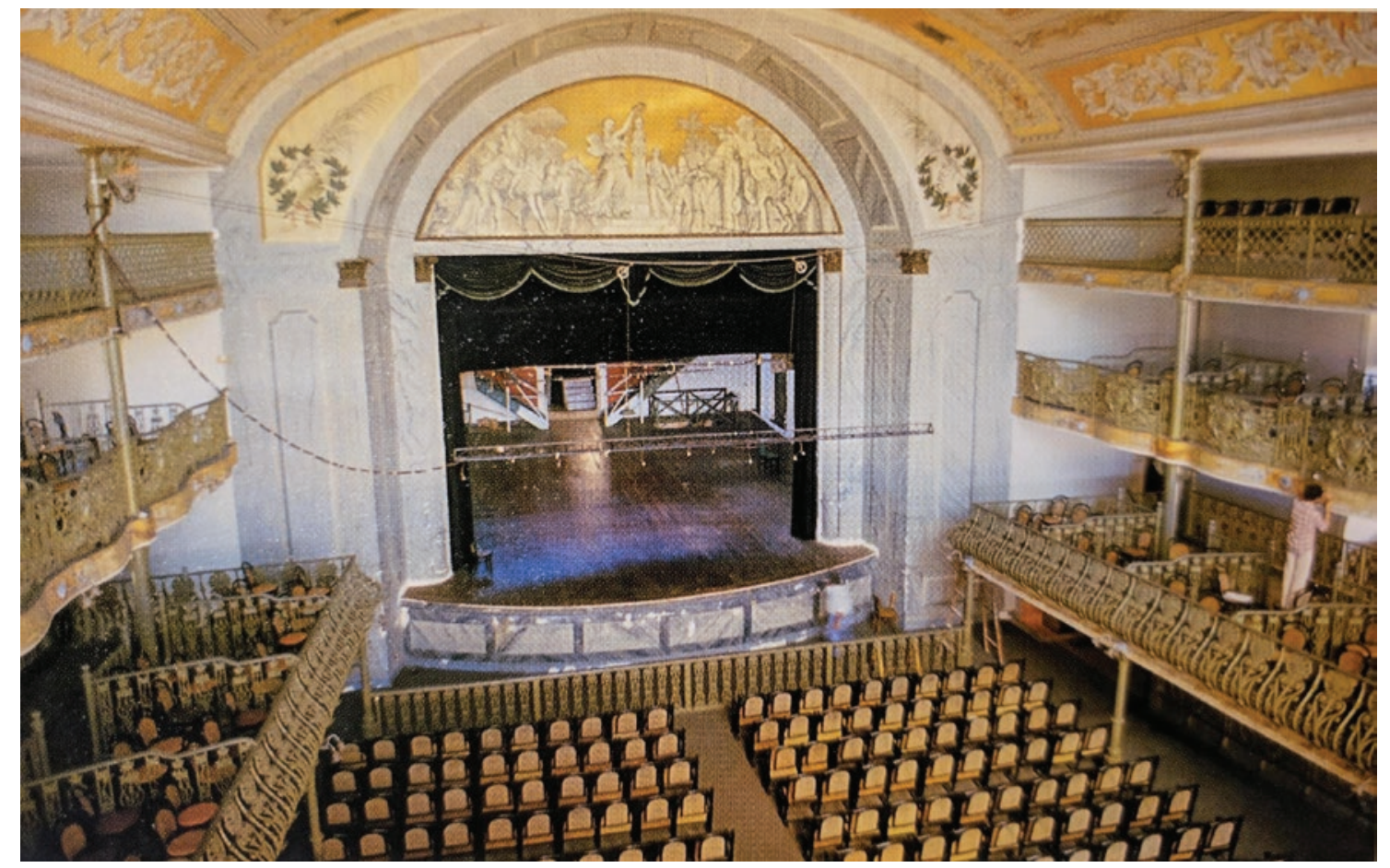

Figura 2 - Vara Frontal de lluminação Cênica, no Theatro José de Alencar. Fonte: Barroso (2002).

A importância da vara frontal e sua correta localização na plateia, proporcionaria qualidades técnicas ao iluminador, que poderia alcançar novas angulações e posicionamentos, necessários para implementações artísticas. No caso do Theatro José de Alencar, além da necessidade da utilização de projetores cênicos, nessa po-

\footnotetext{
10 Trecho da entrevista concedida a Walter Façanha Freitas por Luiz Haroldo Cavalcante Serra no dia 11 de abril de 2019.
}

Walter Façanha Freitas 
sição, os equipamentos disponíveis há 40 anos, não tinham qualidade, nem potência, para serem posicionados em uma vara à frente do balcão da frisa. Sem falar da impossibilidade de uma angulação correta, um projetor de luz, instalado nesta vara, distante $20 \mathrm{~m}$ da borda do palco, não conseguia projetar a luz com brilho suficiente, para a visualização dos espectadores. Nos tempos atuais, já existem projetores cênicos com características que proporcionem um brilho e potência adequados à cena. Mas a questão da angulação ainda não pode ser solucionada. Não depende de equipamentos, e sim da existência da vara frontal, na posição adequada. A falta dela gera complicações, como no relato de um entrevistado, Jorge Silveira:

Todos os mapas luminotécnicos que chegam ao Theatro José de Alencar, apresentam a existência da vara frontal. Isso acaba sendo um problema grande, porque as Companhias não esperam chegar em um Teatro que não tenha a vara frontal. Aí as adaptações acontecem em cima da hora. $E$ às vezes as adaptações não acontecem da forma que deveriam, como aconteceu no Palco Giratório de 2018, onde um espetáculo do Rio Grande do Sul, de teatro de bonecos, precisava de um tipo de iluminação, que só seria alcançada com uma vara frontal. Esse espetáculo aconteceu, porque não tinha como transferir, de última hora, para outro espaço. ${ }^{11}$

Porém, nessa reforma, não aconteceram mudanças arquiteturais na caixa cênica do Theatro. As correções estruturais foram realizadas, mas as características de manobra e quantidade de varas cênicas, foram mantidas como originalmente, sem adequações às tecnologias da época atual, como relata Francisco Veloso:

\begin{abstract}
Após a reforma de 1973, as varas de cenário e iluminação permaneceram as mesmas, continuaram os camarins presentes nas áreas de coxias, dois ou três de cada lado, com banheiros, o que fazia com que as coxias fossem super pequenas, estreitas, o que sempre causou problema, principalmente para as Companhias de dança, que, em determinadas coreografias, o artista terminava a dança em cima da parede dos camarins. $O$ Theatro continuava também sem ar condicionado. A vara frontal, na área de plateia, foi mantida. A reforma de 1973 foi a de maior porte, no ponto de vista estrutural, já que as longarinas estavam vazadas, pela corrosão, mas não alterou a forma nem as características técnicas do palco e plateia. ${ }^{12}$
\end{abstract}

De forma semelhante à reforma de 1973, onde o Theatro estava prestes a colapsar, no ano de 1989, o José de Alencar voltou a enfrentar uma situação-limite. Estava bastante degradado. Nessa época, recuperar o Theatro seria uma estratégia de tentar revitalizar o centro da cidade de Fortaleza. Essa estratégia faz todo o sentido, porque a existência dos espaços teatrais se dá na relação com o público e com a cidade. Todos os entrevistados, da área técnica, aos ligados mais às políticas culturais, concordaram em um aspecto: a importância na revitalização do bairro onde o Theatro se estabelece. A diretora do equipamento, Selma Santiago, nos fez o seguinte relato:

O Theatro José de Alencar não tem estacionamento, e nem uma praça iluminada na frente do Theatro, aliás, a Praça José de Alencar está abandona-

\footnotetext{
11 Trecho da entrevista concedida a Walter Façanha Freitas por Jorge Luiz Alves da Silveira no dia 18 de abril de 2019.

12 Trecho da entrevista concedida a Walter Façanha Freitas por Francisco Augusto Sales Veloso no dia 23 de abril de 2019.
} 
da pela Prefeitura, apresenta ocupações irregulares, com ações ilegais. Isso provoca um ambiente estranho de chegar ao Theatro. Também tem a questão estrutural, já que não tem poltronas confortáveis. $E$ a plateia ficou mais exigente, nesse sentido. Não se pode vender ingressos on line, devido à uma questão burocrática, já que o Theatro não tem um CNPJ. Isso já afasta uma série de pessoas. Alguns eventos âncora estão trazendo um público até três vezes maior para o Theatro. Mas precisa-se de aporte financeiro para trazer esse tipo de espetáculo. O mais importante mesmo, é que a ocupação do Centro da cidade tenha um ordenamento..$^{13}$

Nesse sentido, Oswald Barroso corrobora com o pensamento de Selma Santiago:

O grande problema é a deterioração do Centro da cidade. À noite passou a ser menos frequentado e houve o aumento do risco de quem frequenta essa área, nesse horário. Na década de 90 , acreditávamos que o Theatro ia ajudar a erguer essa área da cidade. Mas para isso acontecer, precisariam de outras e outras iniciativas. Até agora está ganhando a tendência negativa, do Centro ser abandonado. Isso é um problema nacional. Só pode ser resolvido com uma política de ocupação dessas áreas. Só o investimento na estrutura do Theatro e na política de captar grandes espetáculos não é determinante. ${ }^{14}$

Diferente da reforma anterior, a secretária de Cultura do Estado do Ceará, Violeta Arraes, entendeu que deveria buscar mão de obra mais especializada e reconhecida no Brasil. Uma empresa ficou à frente da restauração, Solé \& Castro, com sede em Porto Alegre. Eles procuraram ouvir os artistas e público, para fazer com que a reforma se adequasse às qualidades originais do Theatro, mas também atender às exigências contemporâneas da arte teatral (Barroso, 2002). Dessa forma, pode-se dizer que essa reforma foi a primeira que dedicou uma atenção aprimorada à caixa cênica e seus recursos, ou seja, a área de plateia teve sua importância, mas a área técnica foi, pela primeira vez, destacada, em uma grande reforma. Essas alterações deixaram o Theatro no mesmo nível técnico das melhores salas de espetáculos do país, entregando uma caixa cênica com varas de iluminação motorizadas, varas de cenário contrapesadas e áreas de bastidores adequadas, que passaram a estar aptas a atender às mais exigentes demandas técnicas de espetáculos contemporâneos. Ismael Solé, envolvido com a reforma de 1991, nos conta que: "o Theatro José de Alencar recebeu, na época da reforma, o máximo que existia em desenvolvimento tecnológico na área de iluminação cênica. O problema era que, em 1991, ainda era a iluminação analógica. E a tecnologia, nessa área, se desenvolve muito rápido"15. Veloso nos informou mais detalhes dessa reforma:

Na reforma de 1991, finalmente os camarins e os banheiros, tanto da direita, quanto da esquerda, foram retirados da área de coxia, o que deixou esse espaço mais amplo, consequentemente facilitava a parte técnica. Daí a boca de cena também foi mexida. Ela era menor, se não me engano, $92 \mathrm{~cm}$ de cada lado, o que significou um aumento de $1,84 \mathrm{~m}$ da largura da boca de cena. Foi um dos pontos polêmicos, assim como a retirada dos camarins. Outra coisa, era que não existia o Fosso, na época. Outra coisa polêmica, que foi

\footnotetext{
13 Trecho da entrevista concedida a Walter Façanha Freitas por Selma Maria Santiago Lima no dia 4 de abril de 2019.

14 Trecho da entrevista concedida a Walter Façanha Freitas por Raimundo Oswald Cavalcante Barroso no dia 10 de abril de 2019.

15 Trecho da entrevista concedida a Walter Façanha Freitas por Ismael Geraldo Acunha Solé no dia 10 de abril de 2019. 
implementada na reforma de 1991. Mas quando as escavações foram feitas, foi descoberta a parede de contenção, que é esta que está aí. Então o que foi deduzido, é que, à época, não houve recurso para concluir, ou que não houve tempo para isso ser implementado, já que existia um prazo para a obra ser concluída. ${ }^{16}$

As mudanças na caixa cênica realmente levaram o Theatro José de Alencar para um nível mais elevado, quando se trata de qualidade técnica. As varas de iluminação, anteriormente manuais e presas utilizando as malaguetas, passaram a ser eletro-automáticas, as primeiras do Estado do Ceará. As varas de cenário, pernas, bambolinas, rotunda e ciclorama, ganharam contrapesos e um novo sistema de movimentação, através de roldanas de tiro duplo, que proporcionaram que os cenários e demais adereços pudessem entrar e sair totalmente de cena, sem esforço físico do maquinista e com uma velocidade e eficiência muito maior.

O piso do palco não sofreu modificações. Ele apresenta uma inclinação de $2^{\circ}$, que era compatível com as ideias arquiteturais da época, que se utilizava desse recurso para melhorar a visualização da plateia. Na atualidade, aplicar inclinações ao palco não é mais indicado, pois as mesmas trazem prejuízos técnicos e artísticos aos espetáculos. Bailarinos podem torcer tornozelos e perder o equilíbrio, cenários e adereços podem perder a estabilidade e a iluminação cênica, que pode primar por simetrias rígidas, passa a ser ancorada em uma superfície inclinada, que implica em diferenças de níveis. Isso tem que ser considerado, nas adaptações dos projetos luminotécnicos, em palcos com inclinação.

As quarteladas, que foram implementadas na reforma de 1973, foram mantidas, na de 1991. Essa característica técnica permite uma possibilidade luminotécnica muito interessante, que é a iluminação de baixo para cima. Em um palco convencional, a iluminação pode ser projetada de cima e de frente, através das varas luminotécnicas, pelas laterais e fundo de palco, através das torres e suportes de chão, mas só é possibilitado a projeção proveniente do fundo do palco, se o mesmo apresentar quarteladas. E essa possibilidade luminotécnica é muito utilizada em espetáculos artísticos contemporâneos.

O Theatro foi equipado com o sistema de iluminação analógico, instalado pela divisão Hallstage da Thyssenkrup. Esse sistema aposentou a antiga mesa do espaço, sem tantos recursos. O Theatro continuou com esse sistema analógico, até a data de 2009, quando recebeu equipamentos digitais, através da Funarte. Evoluir do sistema analógico para o digital, significou um aumento considerável de possibilidades luminotécnicas. Passar a utilizar o padrão de tecnologia mais utilizados na maioria dos espaços teatrais do mundo garantiu ao Theatro uma qualidade luminotécnica muito maior. Essa tecnologia digital permitiu que a iluminação do espetáculo pudesse ter um maior número de canais e que estes pudessem agrupar um maior número de dimers, sem as limitações de potência elétrica, impostas no sistema analógico. As gravações de cenas passaram a permitir a gravação de mais canais, de forma mais eficiente e operacional. As operações dos espetáculos passaram a se utilizar de recursos de temporização das cenas, o que reduziram os riscos de erros entre as cenas

16 Trecho da entrevista concedida a Walter Façanha Freitas por Francisco Augusto Sales Veloso no dia 23 de abril de 2019.

Walter Façanha Freitas

Francimara Nogueira Teixeira

Gilson Brandão Costa

Urdimento, Florianópolis, v.1, n.37, p. 290-311, mar/abr 2020 
e garantem uma qualidade superior de operação, nunca antes experienciada pelos operadores luminotécnicos.

Liberar as áreas de coxias, que estavam anteriormente abrigando camarins, também foi essencial para esse salto de qualidade. Cenários maiores passaram a poder sair e entrar pelas laterais, assim como os artistas ganharam mais espaço para as entradas e saídas de cena. Possibilidades luminotécnicas foram aprimoradas, com a liberação das coxias, já que as laterais do palco passaram a ter profundidade suficiente para a instalação de projetores cênicos entre as vestimentas cênicas. E recursos de amarrações cenográficas também passaram a ser possíveis, permitindo novos recursos técnicos da contemporaneidade. Um detalhe, que implica na continuidade da impossibilidade de atingir a escuridão, como possibilidade luminotécnica no palco do Theatro, foi o surgimento de esquadrias, dentro da caixa cênica. Quando os camarins foram retirados, a equipe da reforma, com aval do Iphan, optou por deixar as esquadrias existentes originalmente, na parede lateral do palco, já que a plateia apresentava também as mesmas esquadrias originais da época.

Antes da reforma de 1991, a iluminação era operada de dentro do palco. A mesa de controle de iluminação cênica ficava instalada na lateral do palco, próximo à cortina principal. Segundo Veloso:

A mesa de iluminação funcionava na lateral, dentro do palco. Na reforma de 1991, ela passou a ficar na frente, na área da Torrinha. E para resolver a quantidade de público que foi reduzido, pela criação da cabine técnica, foi criada uma arquibancada, ao lado da mesma. ${ }^{17}$

Essa mudança no posicionamento da mesa de iluminação e criação de uma cabine técnica, trouxe a possibilidade luminotécnica de se operar o espetáculo em uma visão adequada, ou seja, de frente para a cena, e elevou a qualidade técnica do espaço cênico. Em um palco à italiana, onde a plateia fica posicionada sempre à frente do palco, pedindo um tipo de direção artística que tome partido dessa situação, fazer com que o operador da iluminação também esteja à frente, possibilita uma forma de operação mais coerente com o formato desse tipo de palco. No caso do Theatro José de Alencar, a cabine técnica foi posicionada à frente e acima de todos os espectadores, na área da torrinha. Essa posição permite que o operador de iluminação veja toda a área de atuação, porém é a localização mais distante possível da cena. Isso significa que o operador da iluminação precisa poder enxergar bem para conseguir ver detalhes da cena, a $25 \mathrm{~m}$ aproximadamente da cabine. E ter uma atenção redobrada em ouvir deixas para as mudanças de cena, já que a distância também prejudica a audição. Uma questão que está indiretamente ligada à essa pesquisa, revela que essa posição atual da cabine técnica não favorece também as questões da sonorização cênica. Os operadores de som reclamam da posição em que a mesa de som, que controla o sistema de $\mathrm{PA}^{18}$ está. E, para a operação de iluminação, é importante a proximidade com o operador de som, já que muitas deixas para as mudanças de cenas, podem ser provenientes dele, ou do tempo da sonoplastia. $\mathrm{Na}$ atualidade,

\footnotetext{
17 Trecho da entrevista concedida a Walter Façanha Freitas por Francisco Augusto Sales Veloso no dia 23 de abril de 2019.

${ }^{18} \mathrm{PA}$ - Public Address. $\mathrm{O}$ som endereçado à área de plateia.

Walter Façanha Freitas

Francimara Nogueira Teixeira

Gilson Brandão Costa 
os operadores de som e luz escolheram um local alternativo para a posição de suas mesas de controle, que é atrás do balcão da frisa. Fica bem mais próximo ao palco e a sonoridade é bem mais eficiente. Porém, a visibilidade da cena é piorada, devido à proximidade da plateia. E a comunicação entre os operadores acaba sendo prejudicada, já que qualquer som emitido por eles pode ser escutado pela plateia posicionada à $3 \mathrm{~m}$ de distância.

Outra implementação realizada, na reforma de 1991, foi a agregação de um anexo, equipando o Theatro com salas, para áreas administrativas, de capacitação e ensaios e um espaço para pequenas apresentações. Isso elevaria o patamar do espaço, que não serviria apenas para receber apresentações, mas serviria como um centro irradiador de cultura, onde viriam a acontecer diversos cursos para capacitação de alunos nas áreas de iluminação, inclusive. Nomes como Jorginho de Carvalho e Roberto Gil Camargo contribuíram, passando seus ensinamentos, à técnicos e artistas locais.

Após essa reforma de 1991, o Theatro passou por uma nova reforma, no ano de 2005, que contemplou as seguintes áreas: coberta, fachadas, saguão, foyer, pátio nobre, palco, plateia, frisas, camarotes, jardim, camarins, copa, porão, instalações hidráulicas, instalações de ar-condicionado e Teatro Morro do Ouro. Infelizmente, não foram contemplados serviços que proporcionassem melhorias significativas na iluminação do referido espaço teatral ${ }^{19}$.

Como o referido espaço teatral é um equipamento estratégico, no centro de Fortaleza, para a produção e difusão cultural, além de ser patrimônio histórico, existe sempre uma preocupação em manter e melhorar as políticas públicas que o ajudam a continuar exercendo essas funções ao público. Seminários são sempre realizados, para abordar esse tema. Um deles, que teve reconhecida relevância, aconteceu nas datas 14, 15 e 16 de junho de 2004, um ano antes de uma grande reforma. Se chamou "Quando 2010 chegar - O Theatro e a cidade que queremos", e reuniu intelectuais, universitários, artistas, técnicos e formadores de opinião. O objetivo principal do mesmo, foi sensibilizar o poder público e a sociedade civil, para a importância do TJA. Passada quase uma década, após a data expressa no título desse seminário, o quadro do Theatro José de Alencar continua a ser muito parecido, um equipamento cultural imprescindível para o Estado, carente das mesmas políticas públicas.

Nas datas 10, 11 e 12 de junho de 2018, no foyer do Theatro José de Alencar, aconteceu o "Encontro dos Teatros Monumentos". Reuniu pessoas ligadas a diversos espaços teatrais que são patrimônios culturais e que guardam, em sua história e arquitetura, a história cultural do país e uma ligação forte com a sociedade que se utiliza deles. Esse encontro teve o objetivo de fortalecer as políticas culturais, para os teatros monumentos. Foi importante, ao trazer pessoas ligadas às reformas principais no TJA, que explanaram seus desafios, à frente dessa árdua tarefa.

\footnotetext{
${ }_{19}$ Informações colhidas na livro Theatro José de Alencar De Corpo e Alma, publicado em 2007 pelo Governo do Estado do Ceará e pela Fundação Amigos do Theatro José de Alencar, em comemoração às obras de restauração finalizadas em 2005, com apoio do BNDES e da Breitener Energética S/A. 


\section{O Theatro, a arte e a técnica}

Para as visitas técnicas dessa pesquisa ao Theatro José de Alencar, para que as mesmas fossem produtivas e a coleta de dados fosse a mais relevante possível, elaboramos um guia orientativo. $O$ referido guia contém informações importantes para o entendimento das instalações cenotécnicas do Theatro José de Alencar, direcionando o pesquisador aos dados mais significativos para os objetivos desse estudo, de forma a desvendar as possibilidades e não possibilidades luminotécnicas desse espaço, após as observações in loco e o confronto dessas observações e dados, com as pesquisas previamente apresentadas.

Foram realizadas medições das iluminâncias $\left(l u x^{20}\right)$, nas seguintes áreas do Theatro: pátio da entrada, que não é coberto; depois seguem as áreas cobertas e na área da caixa cênica, como fosso da orquestra, proscênio, meio do palco e fundo do palco; depois seguem as áreas de plateia, térreo próximo ao palco, meio da plateia e fundo da mesma (mais próximo à parede de vidro), frisa (lado direito próximo ao palco), frisa (meio do balcão), frisa (lado esquerdo próximo ao palco), camarote (lado direito próximo ao palco), camarote (meio do balcão), camarote (lado esquerdo próximo ao palco), torrinha (lado direito próximo ao palco), torrinha (meio fundo - próximo ao letreiro) e torrinha (lado esquerdo próximo ao palco). As medições de iluminância, nessas áreas, foram realizadas em 3 horários distintos: 9h, 14h e 19h. Ressaltando que nessas datas, o pôr do sol aconteceu às 17:29h. Esses horários foram escolhidos, por serem muito utilizados para apresentações artísticas, no palco principal do Theatro José de Alencar, e por apresentarem uma distância de $5 \mathrm{~h}$ entre elas, o que permitia que as áreas de plateia e palco recebessem a luz externa (natural ou artificial) em posições diferentes. O preenchimento desses dados está presente na Figura 3.

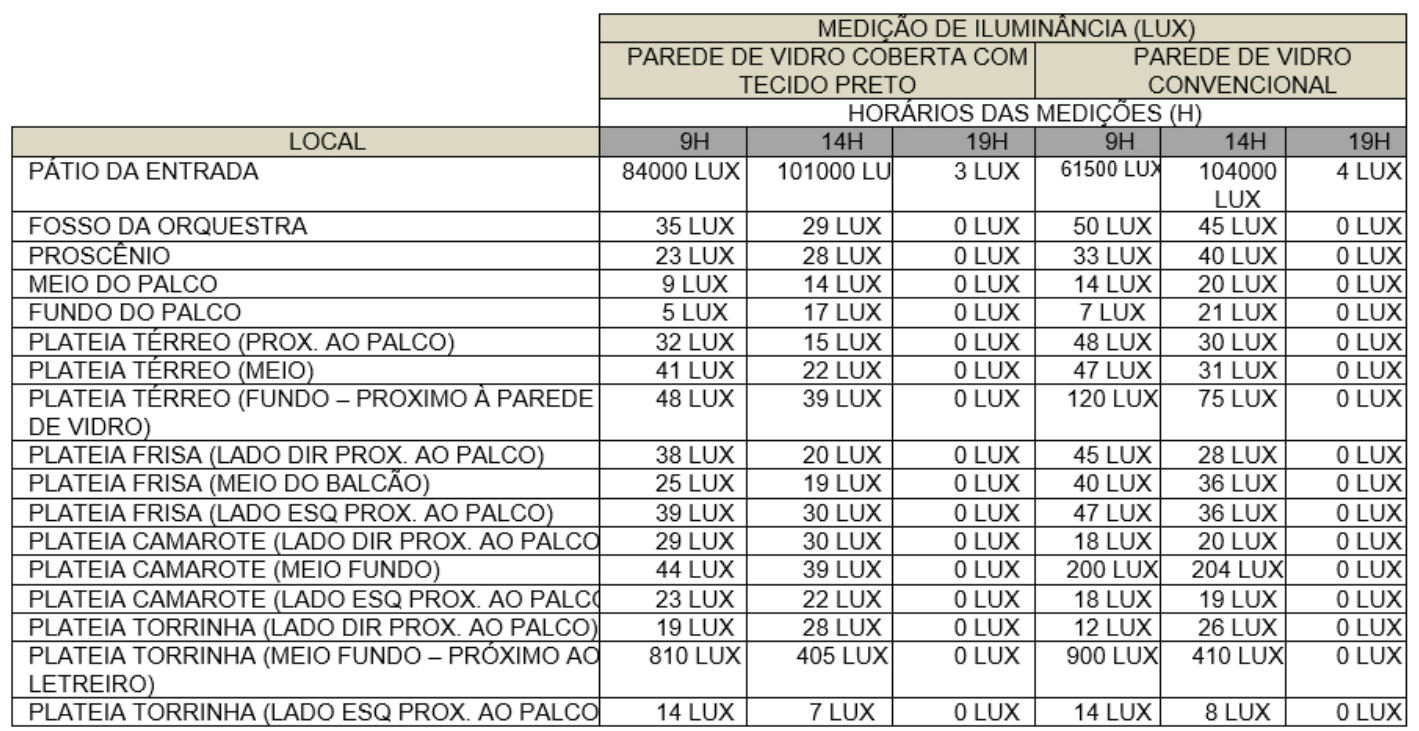

Figura 3 - Medição de lluminância no Theatro José de Alencar, nas visitas técnicas

\footnotetext{
${ }^{20}$ Unidade de iluminamento, densidade de intensidade luminosa ou iluminância. Corresponde à intensidade perpendicular de 1 lúmen em uma superficie de 1 metro quadrado. A visão humana é capaz de perceber bem as formas, a partir de densidade de intensidade luminosa, na casa de 10 lux (Martins, 2004). Em uma noite de lua nova, é possível se medir 0,01 lux, enquanto na lua cheia, essa medida passa a ser de 0,25 lux.

Walter Façanha Freitas

Francimara Nogueira Teixeira

Gilson Brandão Costa 
O Theatro José de Alencar foi concebido para ter sua plateia ligada à um jardim, ou seja, não possuir paredes, recurso esse implementado de forma a não levantar obstáculos à entrada de ventilação natural e manter uma temperatura suportável para os espectadores. Como isso não funcionou, devido às condições climáticas da cidade de Fortaleza, o ar condicionado foi a solução encontrada para resolver esse problema, instalado na reforma de 1991. Para que a iluminação do sol dos trópicos iluminasse a plateia, da mesma forma que o jardim, foi escolhido uma parede de vidro transparente, para que a arquitetura original fosse preservada ao máximo. Essa solução, a princípio, não foi autorizada pelo IPHAN do Estado do Ceará, como informado por Solé:

O Theatro era aberto para o pátio interno, então você não tinha como colocar ar condicionado. A solução era o fechamento em vidro. Mas o IPHAN era contra, porque iria refletir no vidro a fachada do outro bloco. Foram feitos infinitos estudos de forma de colocação do vidro, de forma que esse problema fosse sanado. Mesmo assim, recebíamos negativas do IPHAN. Passamos a entender que a questão do reflexo da fachada era um ponto, mas que eles realmente não estavam convencidos da ideia de colocar um vidro na plateia do Theatro. ${ }^{21}$

Solé informou que a Secretaria de Cultura da época, apelou ao IPHAN nacional para que essa liberação ocorresse. Após a instalação dos vidros, em todas as possíveis entradas e saídas de ar, da área de plateia, o ar condicionado realmente pôde coexistir com a iluminação natural, que continuava a banhar a área de plateia, tanto diurna, quanto nos períodos noturnos. Dessa forma, o problema do conforto térmico estava solucionado. Porém, a possibilidade luminotécnica da escuridão continuava sem solução.

Uma das visitas técnicas foi escolhida em uma data em que o Theatro recebia um espetáculo chamado "O Sítio da Amizade". Essa escolha se deu, porque esse espetáculo apresentava uma necessidade específica acerca da iluminação cênica. Ele precisava da ausência da luz em cena, da escuridão. Como a estrutura arquitetônica do Theatro José de Alencar não permitia que isso pudesse acontecer, a produção do espetáculo, juntamente com a do espaço teatral, providenciou cortinas para diminuir a entrada da luz natural, no interior do estabelecimento. Após a primeira seção do espetáculo, que ocorreu às 8:30h da data 17/04/2019, a visita técnica foi iniciada às 9:30h. A partir dela, foi feito a medição de iluminância nas áreas da plateia e palco do Theatro, assim como registros fotográficos.

De acordo com a medição (Figura 3), nenhuma área medida apresentou iluminância a níveis que se verificasse a escuridão. Os números revelam o que se vê nas figuras 4, 5, 6 e 7, que são fotografias de minha autoria, uma quantidade de luz natural e artificial muito forte, proveniente do ambiente externo à parede de vidro e portas e janelas da plateia do Theatro e da caixa cênica, com e sem a utilização de cortinas.

21 Trecho da entrevista concedida a Walter Façanha Freitas por Ismael Geraldo Acunha Solé no dia 10 de abril de 2019. 


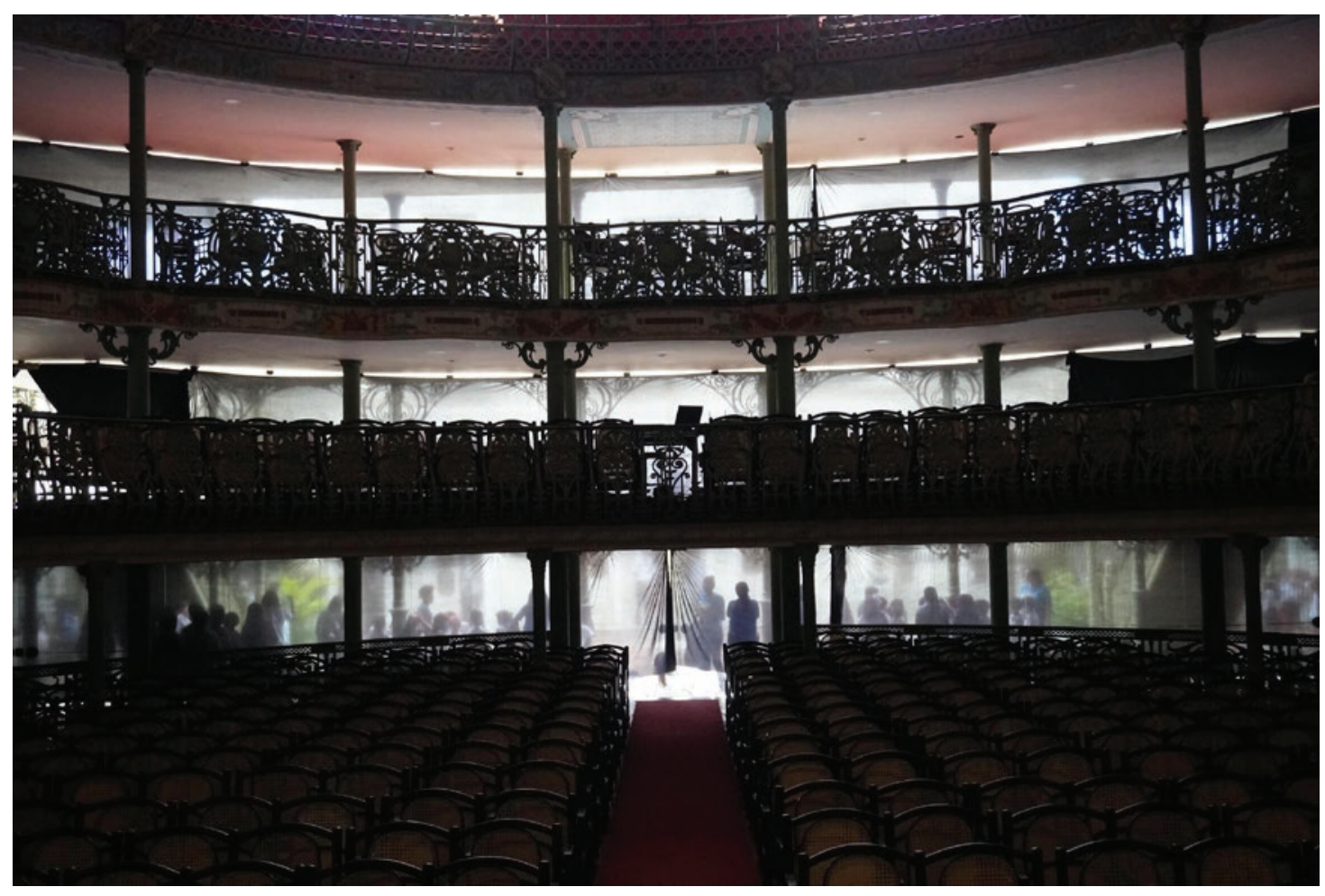

Figura 4 - Registro da cortina de vidro do Theatro José de Alencar, coberto com tecido preto. Fonte: Arquivo pessoal de Walter Façanha Freitas (2019).

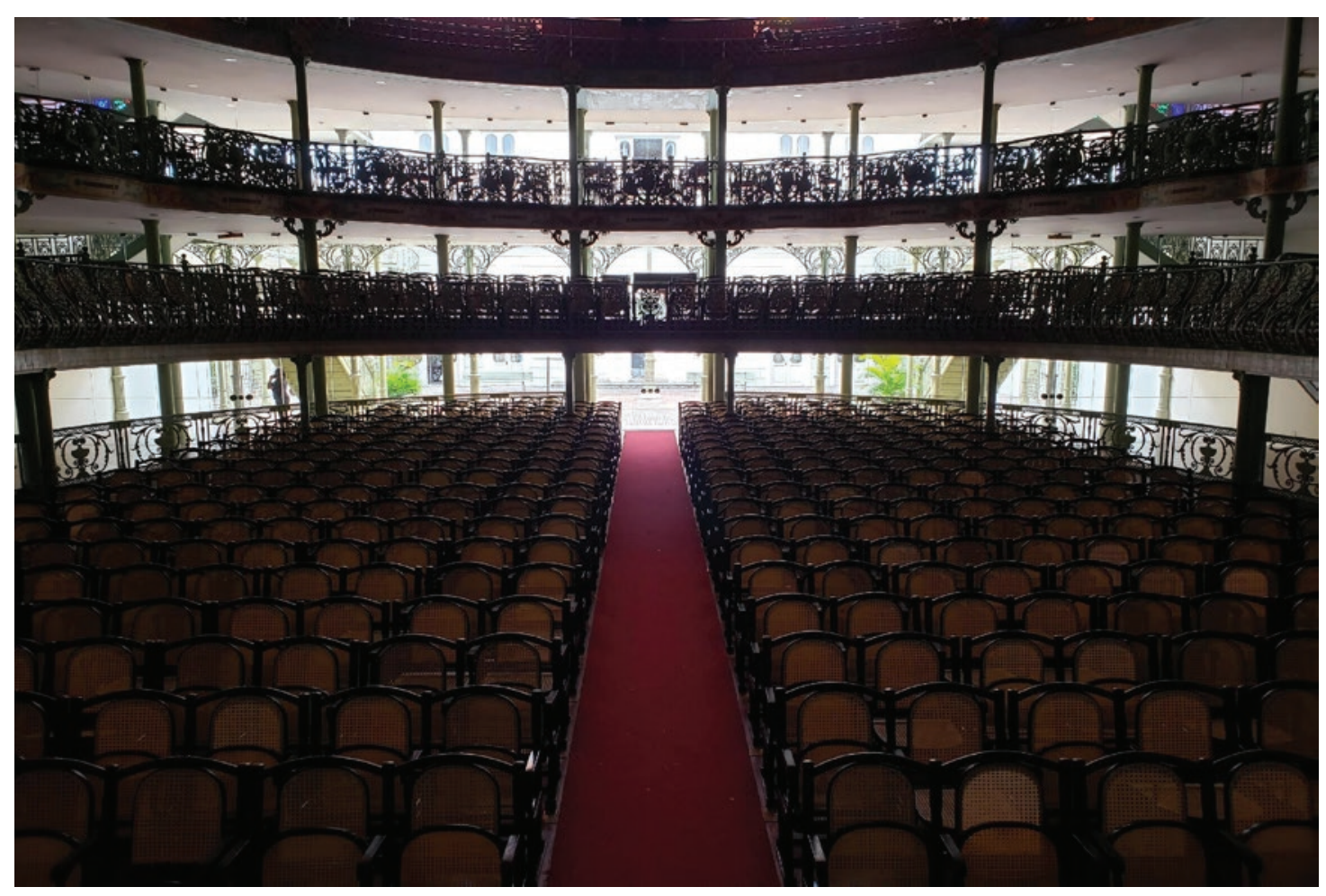

Figura 5 - Registro da entrada de iluminação externa na plateia do Theatro, às $9 \mathrm{~h}$ Fonte: Arquivo pessoal de Walter Façanha Freitas (2019). 


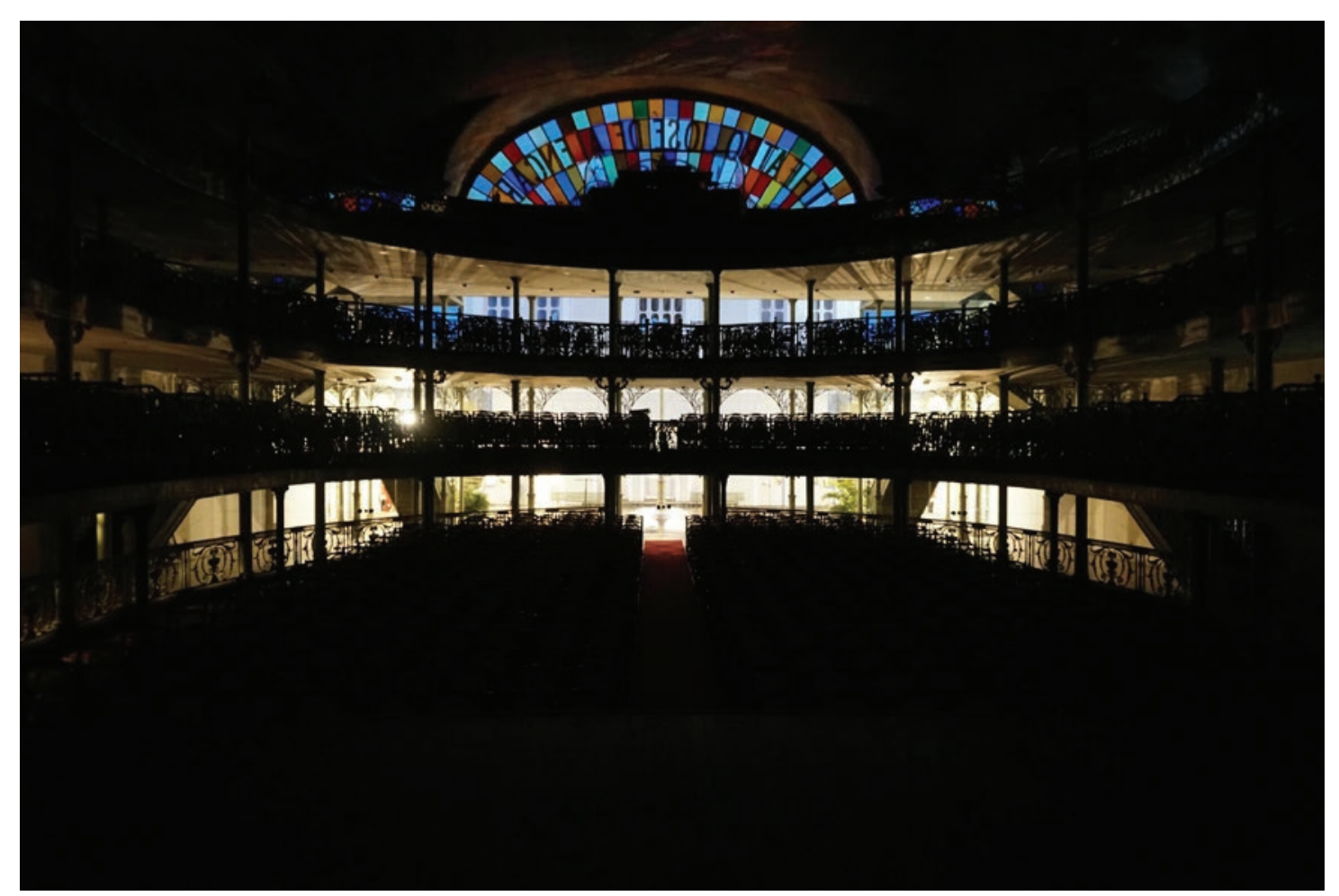

Figura 6 - Registro da entrada de iluminação externa na plateia do Theatro, às $19 \mathrm{~h}$ Fonte: Arquivo pessoal de Walter Façanha Freitas (2019).

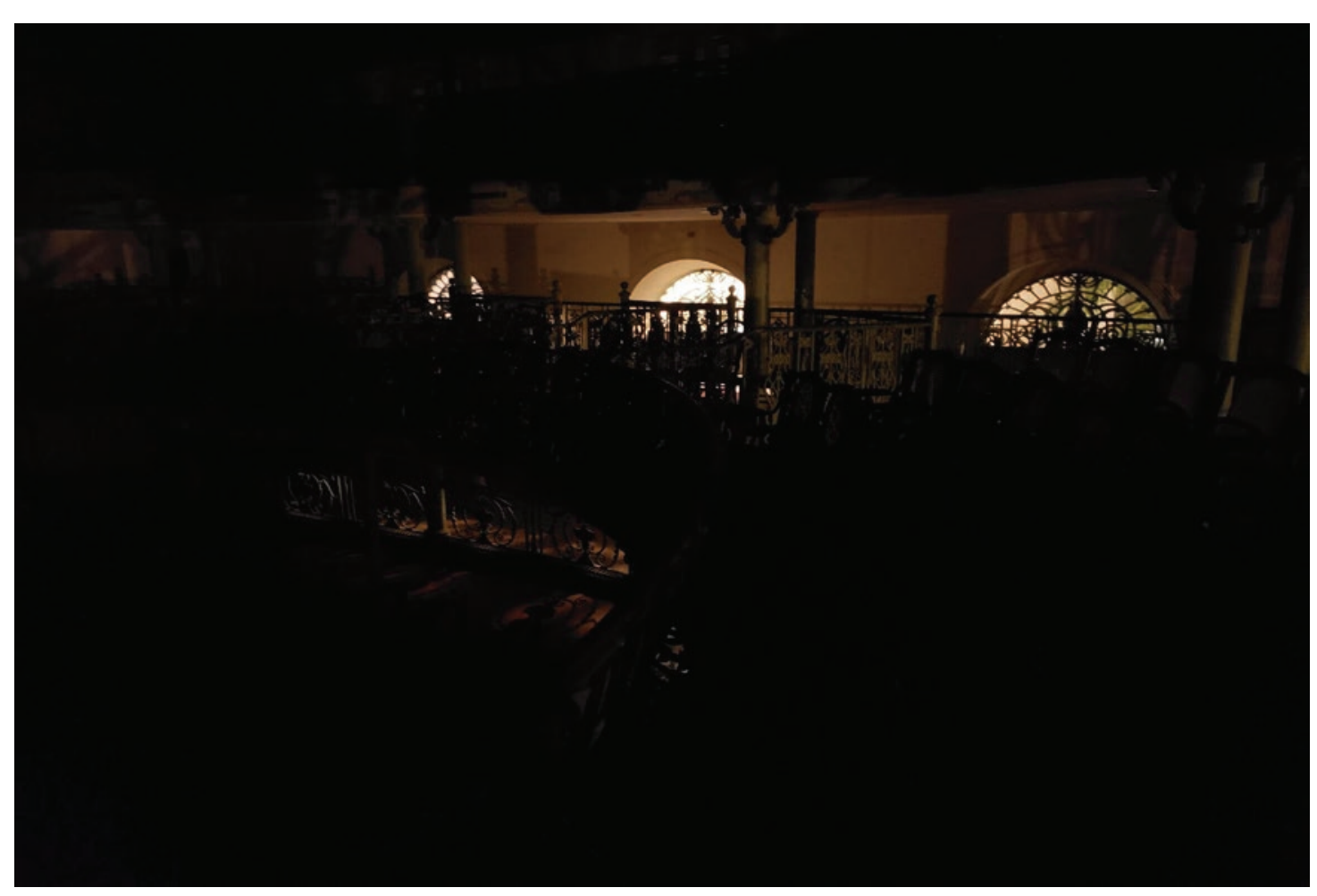

Figura 7 - Registro da entrada de iluminação externa na plateia do Theatro, às 19h Fonte: Arquivo pessoal de Walter Façanha Freitas (2019).

O projeto luminotécnico tem uma importância elevada no resultado artístico final do espetáculo. A partir dessa informação, as visitas técnicas que realizamos nessa pesquisa também tiveram o intuito de colher dados referentes às medidas do espaço

Walter Façanha Freitas

Francimara Nogueira Teixeira

Gilson Brandão Costa 
teatral, com uma atenção especial a tudo o que viesse a influenciar a iluminação cênica. Como produto dessas visitas, foram desenhados documentos as built ${ }^{22}$ do palco e plateia do Theatro. Para facilitar a leitura desse estudo e viabilizar a escala utilizada nas plantas e cortes, esses referidos documentos estão apresentados nos apêndices, devido às mudanças de tamanho do papel e orientação de página.

A elaboração desses documentos tem relevante importância, porque acabam sendo o primeiro contato do técnico e artista (que não residem na cidade) com o Theatro José de Alencar. A partir deles, pode se tomar conhecimento de suas reais estruturas e informações cenotécnicas, como largura e altura da boca de cena, profundidade do palco e inclinação do mesmo, quantidade e disposição de varas cenotécnicas tanto internamente, quanto externamente ao palco, medidas do proscênio e fosso de orquestra, assim como disposição da plateia, ao longo dos diferentes níveis da mesma. Essas pranchas têm uma representação gráfica híbrida, a fim de oferecer ao leitor a possibilidade de, a partir das plantas baixas e cortes, compreender a localização e posicionamento das varas cênicas. Inclusive, algumas linhas-guia revelam angulações importantes, que ligam a parte frontal de representações gráficas de equipamentos de iluminação, até a cabeça de um possível ator, em pé na extremidade do proscênio e na linha da boca de cena.

Realizando uma análise, a partir dos dados coletados nas visitas técnicas e formalizados nas plantas e cortes, pode-se afirmar que o Theatro José de Alencar tem uma caixa cênica com qualidades e padrões para receber espetáculos de médio a grande porte. Não apresenta uma boca de cena com largura considerada grande, mesmo com as modificações realizadas na reforma de 1991, que proporcionou um aumento de $21 \%$ na sua largura original. Com a retirada dos camarins, na área de palco, também na mesma reforma, o Theatro passou a ter medidas excelentes de coxias, podendo vir a servir para soluções técnicas e artísticas dos espetáculos. Com relação às medidas de alturas, a boca de cena apresenta medidas convencionais a espaços teatrais desse porte, assim como às internas ao palco, proporcionando possibilidades luminotécnicas que necessitem dessas dimensões, como iluminação de grandes cenários e utilização de projetores cênicos que possuem graus de abertura pequenos. As alturas internas também possibilitam a contra-regragem de cenários padronizados ao tamanho da boca de cena, o que significa qualidade e mais possibilidades técnicas aos espetáculos.

As varas cenotécnicas apresentam diferenciação entre varas destinadas à iluminação cênica, ciclorama e as outras. Essas são eletro-automáticas e apresentam tomadas interligadas aos referidos dimers de potência, dispostos na lateral do palco. As mesmas apresentam um cesto no centro, para recolhimento do cabeamento elétrico. Essas varas destinadas à iluminação cênica, não estão simetricamente distribuídas na caixa cênica. Essa característica inviabiliza algumas possibilidades luminotécnicas que necessitem de simetria, principalmente com a utilização de fumaça ou dispositivos que permitam a visualização dos fachos de luz. Para um uso simétrico

\footnotetext{
${ }^{22}$ As built - Como Construído. Termo utilizado na arquitetura e engenharia, para designar um documento técnico refeito a partir de dados coletados depois da obra pronta, com as medidas reais do estabelecimento.
} 
da iluminação, se faz necessário a utilização de varas cenotécnicas para essa finalidade. Dessa maneira, multicabos para interligar os projetores de iluminação cênica precisam ser adaptados às varas, de forma a realizarem suas conexões aos dimers de potência. Essa mesma prática precisa ser feita, se o iluminador precisar utilizar equipamentos luminotécnicos em qualquer outra vara interna, fora as cinco destinadas à iluminação. A vara utilizada para ancorar a parte superior do ciclorama é convencional, mas a inferior é menor, para permitir seu funcionamento retrátil. Essa característica acaba influenciando o tamanho da outra vara posterior, que precisa também ter seu tamanho reduzido, devido à mesma característica. As demais varas apresentam a mesma característica. São contrapesadas, apresentam sua contra-regragem na varanda apropriada, na lateral superior do palco. Não há endereço definido para as pernas, bambolinas e rotundas, que podem ser utilizadas de acordo com as demandas técnicas dos espetáculos.

Sobre as quantidades e qualidades das vestimentas cênicas do Theatro, estão à disposição um conjunto com 12 pernas de $7 \mathrm{~m} \times 2 \mathrm{~m}, 6$ bambolinas de 1,5m x 11,38m e 2 rotundas de veludo preto de $7 \mathrm{~m} \times 11,38 \mathrm{~m}$. O ciclorama é angulado (com bordas curvas) e opaco (não é translúcido). Essa característica implica na possibilidade luminotécnica de iluminação por contraluz. A única possibilidade é iluminá-lo pela frente. Seu material também não é adequado para receber iluminação cênica, ou seja, não é confeccionado com PVC fosco, mas com lona vinílica com brilho, o que acaba por funcionar como refletor, prejudicando a correta utilização da iluminação cênica.

A primeira planta (01/04) (Planta Baixa - Térreo) (Apêndice A), apresenta o palco e a plateia do Theatro José de Alencar. No palco, além da indicação da medida da largura da boca de cena, se encontram as disposições das varas cênicas, com suas distribuições ao longo da caixa cênica e suas distâncias reais, reveladas pelas cotas próximas ao contra-pesos. Na parte superior desse desenho, há um detalhe, com uma visão ampliada das respectivas varas e suas legendas. As 5 varas destinadas à iluminação cênica, que são motorizadas e apresentam as tomadas interligadas aos dimers, são identificadas por (VL1) à (VL5). Já a vara destinada ao ciclorama, recebe a legenda (CC). A vara que recebe a bambolina mestra, recebe a legenda (VB). As outras 29 varas cênicas, que podem servir para receber cenários, bambolinas, ou pernas, são identificadas como (VC). As varas (VC26) e (VC27) apresentam um tamanho diferenciado para permitirem que o ciclorama seja recolhido, já que a parte superior do mesmo fica na vara (CC), mas a parte inferior é instalada na (VC27).

A segunda planta (02/04) (Planta Baixa - Frisa) (Apêndice B), apresenta as varas de iluminação frontal, presentes na plateia, na altura do piso das frisas. Elas ficam na altura da cabeça de quem está em pé, no palco. Duas varas estão instaladas no lado direito e outras duas, no lado esquerdo da plateia.

A terceira planta (03/04) (Planta Baixa - Torrinha) (Apêndice C), apresenta as varas de iluminação frontal, presentes na plateia, na altura do piso torrinha. Nessa mesma planta, há uma projeção de duas varas de iluminação, instaladas na altura do teto da Torrinha. As varas laterais na altura do piso da Torrinha, proporcionam um ângulo de $45^{\circ}$ para quem está em pé, no proscênio. Já as varas instaladas na altura do teto da Torrinha, proporcionam esse mesmo ângulo, para quem estiver em pé, na boca de cena. Por esse motivo, são varas bastante utilizadas, para iluminação no Theatro. A 
vara frontal curva, já não oferece ângulos muito usuais para iluminações frontais, mas são importantes para aumentar os recursos técnicos ao Theatro.

O último documento (04/04) (Corte Lateral) (Apêndice D), apresenta todas as varas do palco e plateia, assim como diversas cotas relacionadas à altura, como a da boca de cena e a do piso do urdimento ao palco. Esse corte deixa claro a assimetria das varas internas destinadas à iluminação cênica. As varas externas receberam desenhos de equipamentos, que ajudam a visualizar a relação das mesmas com a angulação em diferentes posições no palco. Nesse documento, também se percebe a inclinação do piso do palco e a disposição reta das poltronas da plateia, no piso térreo.

A partir das informações, dispostas nesses documentos, desenhados de acordo nas escalas de $1 / 200$ e $1 / 75$, os técnicos e artistas encontram as primeiras ferramentas para adaptarem suas obras ao referido espaço teatral, antes mesmo de chegarem fisicamente ao local. Daí, acreditamos que através da técnica, podemos oferecer aos criadores e técnicos instrumentos mais precisos para o seu trabalho. Até antes da elaboração dos documentos gerados por essa pesquisa, os artistas e técnicos não tinham acesso à essas informações, dessa forma, porque o TJA não possui nenhum guia orientativo com essas características. Tudo era passado oralmente, o que não garantia uma qualidade técnica às adaptações técnicas e artísticas dos espetáculos e deixava as companhias vulneráveis às incertezas cenotécnicas, que seriam averiguadas apenas na chegada ao espaço teatral. E o tempo disponibilizado para as questões luminotécnicas costuma ser reduzido, tanto pela alta frequência de espetáculos que se utilizam do Theatro, quanto pela particularidade de não se conseguir uma escuridão nas áreas de palco e plateia. Essa questão impacta diretamente na afinação dos projetores de iluminação cênica. Como a iluminação forte, proveniente do sol, entra através das janelas e paredes de vidro, e chega nas áreas de palco e plateia, afinar uma iluminação ou gravar uma cena na mesa de controle, nessas áreas, é uma tarefa árdua e, dependendo do efeito, impossível de ser alcançada. Então, ter ferramentas para adaptar o projeto luminotécnico, antes de chegar ao espaço, é muito importante.

\section{Considerações finais}

As transformações na cena teatral, que caracterizam o teatro moderno, não aconteceram apenas devido ao desejo forte de ruptura com teorias e fórmulas superadas, mas também devido a descoberta de possibilidades técnicas concretas. Com a implementação dessas mudanças técnicas, as mesmas impactaram poeticamente as possibilidades criativas do palco italiano. A principal ferramenta técnica que impulsionou essa revolução foi a descoberta dos recursos da iluminação elétrica. Essa revolução fez com que a representação figurativa do real e do irreal, pudessem ganhar intensidade e qualidade artística (Roubine, 1998).

Nessa pesquisa, identificar possibilidades e limitações técnicas do Theatro José de Alencar foi o objetivo central. Para tanto, tomamos esse espaço teatral, como estudo de caso. As visitas em campo foram fundamentais para a realização da coleta de dados, dados esses que foram formalizados e analisados por meio da elaboração de tabelas comparativas, plantas arquitetônicas, cortes e preenchimentos do guia orien- 
tativo. A análise desses dados revelou muito das possibilidades e não possibilidades luminotécnicas do Theatro José de Alencar.

As entrevistas realizadas com diretores, artistas, iluminadores e técnicos ligados ao Theatro ajudaram a confirmar as informações encontradas nos livros utilizados para a fundamentação do referido estudo, como fatos relacionados às reformas e, mais ainda, preencheram as lacunas de informações ainda não publicadas, como as relações interpessoais e a história à frente das decisões envolvendo as coevoluções da iluminação e arquitetura acerca desse centenário espaço teatral. No corpo da pesquisa, inserimos trechos dos relatos narrados por boa parte dos entrevistados, articulando-os à história do Theatro, suas reformas e adequações técnicas.

As possibilidades da iluminação estão longe de se estagnar. A cada dia surgem novas tecnologias, como mesas controladoras com mais recursos e precisão técnica, materiais mais resistentes e de dimensões reduzidas, lâmpadas mais econômicas e eficientes. É verdade que a lâmpada com o filamento incandescente ainda reina nos teatros, mas novas tecnologias promissoras já despontam e chegam a ser até mais utilizadas do que elas, para certas finalidades, como na utilização de moving lights ${ }^{23}$ e canhões seguidores ${ }^{24}$, que funcionam melhor com lâmpadas de descarga de vapor metálico. Da vela, passando por lampiões à óleo, a gás, eletricidade, tungstênio, halogênio, laser, LED, todas essas descobertas, como destaca Camargo (2000) estão intimamente ligadas à necessidade do homem de imitar o sol, tanto em suas tarefas domésticas quanto na arte de iluminar um espetáculo.

As mudanças físicas nas salas de espetáculos são justificáveis, na medida em que as mesmas precisam tomar partido dos recursos alcançados pela evolução luminotécnica. Sem implementação de mudanças físicas, os teatros ficam obsoletos e começam a não atender às exigências das encenações contemporâneas, que, em muitos casos, utilizam fortemente os atuais recursos alcançados pela iluminação. Pode-se afirmar que a iluminação cumpre o papel de dramaturgia em muitas criações. Dessa forma, ela realmente desempenha um papel na co-criação dos demais recursos cênicos, como na cenografia, figurino, maquiagem; e na atuação e direcionamentos artísticos (Pavis, 2008).

Defende-se que os teatros, como espaço físico, têm que se renovar, se adaptar, de forma a tomar partido das novas possibilidades da iluminação. A iluminação é tida como uma linguagem. Ela funciona como uma espécie de partitura, que informa o que pode ser visto em cena, no tempo almejado, na intensidade, cores e velocidade previamente concebidos. A iluminação cênica não se torna uma linguagem apenas pela utilização da eletricidade. A eletricidade foi apenas uma ferramenta para chegar a esse fim. E esse processo foi longo. Uma tecnologia surgiu e foi adaptada a uma forma de se criar arte, pesquisando maneiras de como produzir novas experiências visuais aos espectadores, nas suas diversas formas de utilização (Simões, 2015).

A arquitetura dos espaços teatrais deve atuar na edificação, de forma a atender as exigências técnicas que a iluminação cênica demanda e também para que o arqui-

\footnotetext{
${ }^{23}$ Projetores cênicos de iluminação, automatizados, com movimentos e funções controladas remotamente, através da mesa de controle de iluminação.

${ }^{24}$ Projetores cênicos de iluminação, com movimentos e funções controladas fisicamente por um profissional, que o guia de forma a seguir alguém em cena, ou alguma ação no palco.

Walter Façanha Freitas

Francimara Nogueira Teixeira

Gilson Brandão Costa

Urdimento, Florianópolis, v.1, n.37, p. 290-311, mar/abr 2020
} 
teto possa pensar no conforto da plateia e a correta disposição das poltronas é importante, assim como a beleza da sala de espetáculo. Mas quando as luzes da plateia se apagam para que a cena se inicie, o teatro como arquitetura deve dar passagem ao teatro que está em cada criação. E este deve prevalecer. Por isso, pensar em uma arquitetura que privilegie a iluminação cênica é imprescindível.

Ao longo da escrita desse artigo, percebemos algumas limitações referentes ao mesmo, que podem ser tema para aprofundamento de próximas pesquisas dentro dessa temática. Sentimos a necessidade de aprofundamento de pesquisa nos outros teatros monumentos do Brasil, de forma a levantar informações acerca de suas possibilidades e não possibilidades luminotécnicas e sua coevolução na história dos palcos e do teatro. Outro ponto que merece uma pesquisa mais aprimorada, seria o levantamento de soluções para as limitações luminotécnicas encontradas no Theatro José de Alencar. Como, por exemplo, seria muito importante uma pesquisa com a finalidade de solucionar o problema da ausência de escuridão desse referido espaço teatral, diante da sua arquitetura original e por ser patrimônio histórico. Como solucionar esse problema, sem afetar sua originalidade? O mesmo desafio é quando se coloca a possiblidade de existência da vara de iluminação frontal desse espaço teatral. Um estudo para viabilizar a existência da mesma, em harmonia com a arquitetura original seria de uma grande importância para a qualidade artística dos espetáculos que se utilizam de suas dependências.

Esse estudo se mostrou relevante por ter abordado uma temática pouco explorada nos âmbitos científico e literário, tendo como diferencial a verificação das possibilidades de criação luminotécnica, a partir das estruturas físicas de um importante espaço teatral. Por esse motivo, ele contribui para o campo, apresentando um estudo que pode ser ampliado e aplicado em outros espaços teatrais; e também contribui com a classe técnica e artística apresentando as possibilidades e não possibilidades luminotécnicas do principal espaço teatral do Estado do Ceará, além da disponibilização de documentos imprescindíveis às adaptações técnicas e luminotécnicas dos espetáculos que poderão se utilizar das dependências do Theatro José de Alencar, como plantas e cortes arquitetônicos, com a descrições de quantidades e posicionamentos de varas cenotécnicas e cotas de medidas relevantes às referidas adaptações, contribuindo na consolidação da arte em cena, através da luminotécnica.

Acreditamos, ainda, que este estudo também fortalece a luta das pessoas à frente do Theatro José de Alencar, que enfrentam as dificuldades inerentes à coevolução de um espaço teatral centenário, que precisa manter suas características e qualidades técnicas e artísticas, em um cenário político, social e econômico cada vez mais adverso às questões culturais.

\section{Referências}

BARROSO, O. Theatro José de Alencar: o teatro e a cidade. Fortaleza: Terra da Luz Editorial, 2002. 
CAMARGO, R. G. Função Estética da Luz. Sorocaba: TCM Comunicação, 2000.

LIMA, C. I. S. Nos palcos de Fortaleza: o teatro em seus aspectos culturais, sociais e políticos na capital cearense no início do século XX. Anais do XX Encontro Regional de História: História e Liberdade. A NPUH/SP-UNESP-Franca. 06 a 10 de setembro de 2010. CD-ROM

MARTINS, F. R. Níveis de iluminância do céu no alvorecer e no ocaso. Divisão de Clima e Meio Ambiente/Centro de Previsão do Tempo e Estudos Climáticos - Instituto de Pesquisas Espaciais (DMA/CPTEC-INPE), 2004.

PAVIS, P. Dicionário de Teatro. São Paulo: Perspectiva, 1999.

PAVIS, P. A Análise Dos Espetáculos. São Paulo: Perspectiva, 2008.

ROUBINE, J. L. A Linguagem da Encenação Teatral. Rio de Janeiro: Jorge Zahar, 1998.

SIMÕES, C. F. À luz da linguagem - um olhar histórico sobre as funções da iluminação cênica. Sala Preta, São Paulo, v.15, n.2, p.117-135, 2015.

SIMÕES, C. F. À luz da linguagem. A iluminação cênica: de instrumento da visibilidade à "Scriptura do visível". 2013. Tese (Doutorado em Teoria e Prática do Teatro) - Escola de Comunicações e Artes, Universidade de São Paulo, São Paulo, 2013.

THEATRO JOSÉ DE ALENCAR DE CORPO E ALMA. Governo do Estado do Ceará e Fundação Amigos do Theatro José de Alencar. Fortaleza: s/e, 2007.

Recebido em: 30/10/2019

Aprovado em: 12/02/2020 